\title{
STRATEGI KOMUNIKASI LINTAS BUDAYA SEBAGAI JEMBATAN SILANG BUDAYA
}

\author{
Slamet Wiyono, M.Th. \\ Dosen di Sekolah Tinggi Teologi Makedonia Ngabang
}

\section{PENDAHULUAN}

\section{A. LATAR BELAKANG MASALAH}

Indonesia adalah bangsa yang majemuk. Bangsa dengan kepelbagaian di segala aspek dan bidang. Falsafah "Bhineka Tunggal Ika” "Berbeda Tetapi Satu" - menunjukkan keunikan sekaligus asset kekayaan bangsa. Setidaknya itulah maksud yang coba diwujudkan pendiri bangsa ini dengan mencantumkannya pada lambang Negara kita, Pancasila.

Tapi benarkah kepelbagaian itu tetap menjadi kebanggaan bangsa Indonesia? Realitas yang muncul beberapa tahun terakhir sepertinya menunjukkan tafsir berbeda. Alih-alih keunikan bangsa tersebut diuri-uri (dijunjung tinggi), maraknya konflik kedaerahan yang kental nuansa SARA-nya justru menunjukkan sebaliknya. Kemajemukan yang dulu dipandang sebagai kekayaan keanekaragaman itu kini justru kerap dipandang sebagai kambing hitam.

Fenomena semacam ini tentu tidak dapat dipandang sebelah mata. Perlu benar mendapat sentuhan dan perhatian khusus dari banyak kalangan. Tidak sekadar menjadi sumber berita media atau bahan penelitian, tapi disikapi sedemikian rupa untuk meminimalisir, mengecilkan, atau menghilangkan sama sekali konflik-konflik yang mengambinghitamkan perbedaan. Betul, sentuhan antar budaya dalam perbedaannya memang selalu ada. Namun, heterogenitas ini hendaknya tidak menjadikan suku, agama, ras, golongan atau komunitas yang 
homogen lantas menjadi terancam. Benar, kekhasan setiap budaya dengan keunggulannya yang unik itu mampu memantik sentimen kedaerahan. Namun dalam konteks bangsa yang pluri-cultural ini keunikan itu seyogianya justru dijadikan perbendaharaan budaya general, yakni budaya Indonesia. Keunikan di setiap budaya, adat, atau komunitas budaya itu seyogianya memperkaya khasanah budaya Indonesia yang naturnya memang majemuk itu.

Konflik mengatasnamakan agama, ras dan keturunan tertentu, niscaya dapat diminimalisir jika setiap bangsa, pelaku (peserta) budaya memiliki pemahaman yang jujur, apa adanya dan obyektif tentang budaya sendiri, terlebih budaya liyan (the others). Aktualisasi tentang maksud ini dapat diformulasikan terlebih dahulu dalam apa yang dinamakan "Komunikasi Lintas Budaya". Oleh sebab itu, maka kajian terhadap "Komunikasi Lintas Budaya” perlu dilakukan guna menelisik lebih jauh terkait fungsionalitas, urgensi atau unsur pragmatis dari formula dimaksud. Sebab dengan pemahaman dan penerapan yang baik tentang "Komunikasi Lintas Budaya", menurut hemat penulis, orang (Bangsa Indonesia) niscaya dapat saling mengerti, memahami, tepo sliro (toleransi). Bukan semata menjadi bunga tidur, tapi aktual di sepanjang masa.

Tidak itu saja, pemahaman tentang"Komunikasi Lintas Budaya” yang tepat disinyalir juga memiliki peran penting dalam pewartaan berita sukacita dari sorga. "Komunikasi Lintas Budaya" menolong orang, khususnya pelayan Tuhan untuk memahami budaya orang. Pengertian budaya orang dengan baik niscaya dapat menjadi jembatan penghubung yang sangat efisien bagi penyampaian injil Kristus. 


\section{ETIMOLOGI KATA DAN DEFINISI KOMUNIKASI LINTAS BUDAYA}

\section{A. Definisi Komunikasi}

Istilah komunikasi bukanlah hal asing. Setiap hari, menit, bahkan detik bagian hidupnya, orang melakukan apa yang dinamakan dengan komunikasi. Interaksi dua atau lebih orang dalam sebuah komunitas sosial mengindikasikan adanya komunikasi. Tidak dapat dipungkiri jika komunikasi menjadi bagian integral hidup orang yang muskil terpisahkan. Natur manusia sebagai makhluk sosial juga mengandaikan pentingnya komunikasi. Tanpa komunikasi manusia akan menyangkali khitahnya (tujuan dasar/hakikat) sebagai makhluk yang selalu memerlukan interaksi, sosialisasi, adaptasi, dan aktualisasi diri.

Secara etimologis, komunikasi berasal dari bahasa latin "communicatio" yang bersumber dari kata dasar "comminis" yang mengandung arti sama makna mengenai sesuatu hal yang dikomunikasikan ${ }^{1}$. Dalam komunikasi terdapat proses pengiriman dan penerimaan pesan atau berita, antara dua orang atau lebih, sehingga pesan yang dimaksud dapat dipahami; di dalamnya juga terdapat hubungan atau kontak. ${ }^{2}$ Sebagai sebuah proses, komunikasi, seperti dirilis dalam laman ensiklopedia popular Wikipedia digunakan oleh seseorang atau beberapa orang, kelompok, organisasi, dan masyarakat dalam menciptakan, dan menggunakan informasi agar terhubung dengan lingkungan dan orang lain ${ }^{3}$

Komunikasi sebagai proses pertukaran informasi, gagasan, dan perasaan, tidak saja melibatkan indra verbal semata. Menurut Richard L,

\footnotetext{
1 Tommy Suprapto, Pengantar Teori dan Manajemen Komunikasi, MedPress, Yogyakarta, 2008, hlm 4

${ }^{2}$ Kamus Besar Bahasa Indonesia http://kbbi.web.id/index.php?w=komunikasi

${ }^{3}$ http://id.wikipedia.org/wiki/Komunikasi
} 
Weafer, seperti dikutip Dr. Alo Liliweri, dalam proses pertukarannya komunikasi juga dapat dilakukan dengan cara tulisan, menggunakan bahasa tubuh, gaya, maupun penampilan diri, tidak ketinggalan alat-alat Bantu lain di sekitar yang dapat dimanfaatkan untuk memperkaya sebuah pesan, dikenal sebagai komunikasi non verbal. ${ }^{4}$

Sebagai sebuah proses, Joseph De Vito memberi penegasan terkait soal komunikasi dengan mengemukakan, bahwa komunikasi adalah transaksi, di mana komponen-komponen dalam proses komunikasi saling terkait. Keterkaitan yang bersifat integral itu, seperti diungkap Vito, elemen-elemennya saling bergantung (Interdependen), masing-masing komponen saling terkait dengan komponen lain. Komponen-komponen tersebut adalah komunikator, pesan, media, komunikan dan pengaruh. ${ }^{5}$ Pemaparan oleh Vito ini akan lebih lengkap bila disertai dengan ilustrasi langkah-langkah dalam proses komunikasi sebagai berikut:

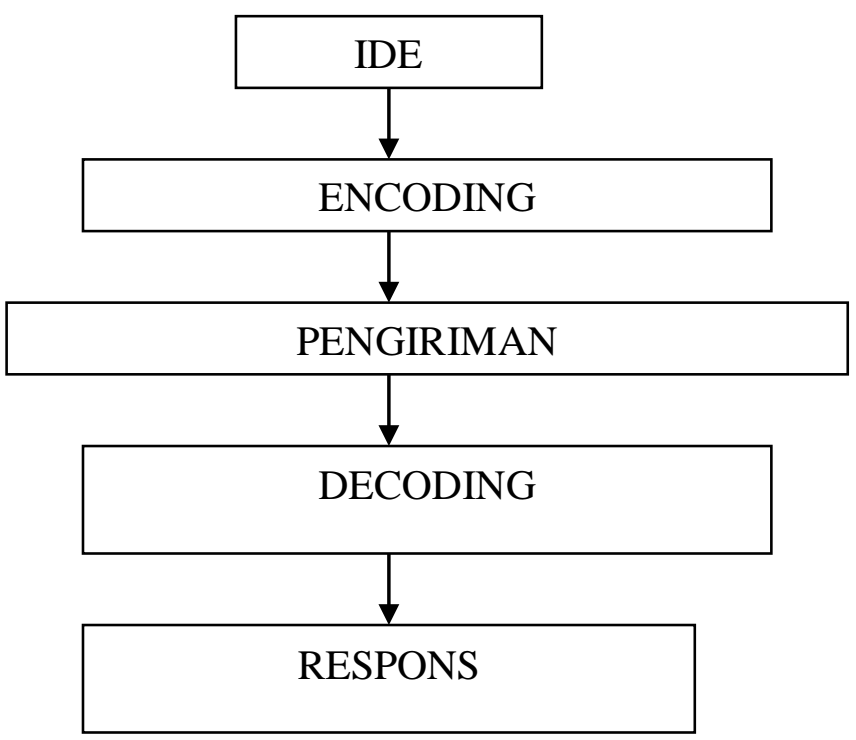
2002, hlm 3

${ }^{4}$ Alo Liliweri, Makna Budaya dalam Komunikasi Antar Budaya, LKIS, Yogyakarta,

${ }^{5}$ Tommy Suprapto, Pengantar Teori dan Manajemen Komunikasi, MedPress, Yogyakarta, 2008, hlm 7 
1. IDE, sesuatu yang diciptakan oleh sumber komunikator. Ide juga berarti gagasan yang hendak disampaikan kepada target atau penerima pesan.

2. Selanjutnya, Ide dalam benak coba dialihbentukkan (converting) ke dalam symbol-simbol tertentu yang memiliki makna.

3. Gagasan yang sudah diubah menjadi symbol itu selanjutnya dikirimkan melalui media-media tertentu.

4. Langkah keempat adalah langkah interpretasi symbol atau menafsirkan pesan sesuai dengan persepsi.

5. Selanjutnya ada umpan balik atau respons terhadap pesan, apabila pesan telah berhasil di tafsirkan. ${ }^{6}$

Proses pengalihbentukan ide menjadi symbol untuk ditafsirkan dan mendapat respons karenanya, an-sich bukanlah perpindahan pesan dari satu person ke person lain semata. Betul, komunikasi adalah pertukaran informasi (pesan) dalam format symbol atau lambanglambang tertentu, tapi sesungguhnya yang terjadi adalah perpindahan makna semata. Makna di sini bukan sekadar kata-kata verbal atau perilaku nonverbal, tetapi makna adalah pesan dimaksud yang diharapkan dapat dimengerti oleh penerima pesan. ${ }^{7}$

Komunikasi, baik diartikan sebagai pertukaran symbol ataukah pertukaran makna, keduanya ada dalam bentuk-bentuk unik, yakni komunikasi antarpribadi, komunikasi kelompok kecil dan besar, organisasi, publik dan massa. Keduanya juga bergerak dari tingkat yang kecil menuju besar. Missal dari komunikasi dua pribadi, menuju kelompok atau komunitas, lalu berlanjut ke lokus yang lebih besar, seperti

\footnotetext{
6 Ibid

${ }^{7}$ Alo Liliweri, Makna Budaya dalam Komunikasi Antar Budaya, LKIS, Yogyakarta, 2002, hlm 6
} 
wilayah atau daerah tertentu. Baik antar daerah ataupun lintas daerah. Antar bangsa, etnis, suku dan budaya atau justru lintas bangsa, etnis, suku dan budaya.

\section{B. Definisi Budaya}

Selanjutnya adalah istilah budaya. Sama seperti komunikasi, budaya juga melekat erat, bahkan dia adalah keseluruhan aspek hidup orang itu sendiri. Bagaimana manusia mencipta, berkarya dalam memenuhi kebutuhan dalam komunitas sosialnya seringkali diidentifikasi sebagai budaya. Simpulan ini didapat dari arti dalam serapan istilah budaya dari bahasa asing. Budaya ditinjau dari asal katanya berasal dari bahasa Sanskerta, yaitu buddhayah, bentuk jamak dari buddhi (budi atau akal) diartikan sebagai hal-hal yang berkaitan dengan budi dan akal manusia. ${ }^{8}$ Sederhananya, bu.da.ya $n 1$ adalah hasil/ produk dari pikiran; akal budi manusia. ${ }^{9}$

Dalam bahasa Inggris kata untuk istilah kebudayaan adalah culture. Berasal dari kata dalam bahasa Latin Colere, yang berarti mengolah atau mengerjakan. Karena itu dari kata dalam bahasa Inggris, kebudayaan memiliki arti sebagai mengolah tanah atau bertani. Kata ini juga telah diserap ke dalam bahasa Indonesia sebagai "kultur". Menurut Raymond Williams, seperti dikutip Romo Mudji Sutrisno, kata culture merupakan salah satu kata yang paling kompleks penggunaannya dalam bahasa Inggris. Disebut kompleks lantaran penggunaan kata ini untuk mengacu pada sejumlah konsep penting dalam beberapa disiplin ilmu yang berbeda sama sekali. Kata culture seperti dikutip Mudji dekat pengertiannya dengan kata "kultivasi" (Cultivation), yaitu pemeliharaan ternak, hasil bumi, dan upacara-upacara religius. Cultivasi diturunkan dari istilah kultus atau cult. Dalam perkembangan selanjutnya, sejak abad ke-16

\footnotetext{
8 http://id.wikipedia.org/wiki/Budaya

${ }^{9}$ Kamus Besar Bahasa Indonesia http://kbbi.web.id/index.php?w=budaya
} 
sampai 19 istilah ini mengalami perluasan arti yang dikaitkan dengan pengembangan akal budi manusia individu dan sikap-perilaku. ${ }^{10}$

\section{Pengertian Komunikasi Lintas Budaya}

Apabila pengertian Komunikasi dan budaya digabungkan, misalnya dalam kalimat "Komunikasi Lintas Budaya", maka tidak sertamerta artinya akan mendekati arti dari istilah keduanya, yakni pertukaran informasi atau makna antar budaya yang berbeda. Pengertian dari "Komunikasi Lintas Budaya" akan jauh lebih kompleks. Di dalamnya terdapat unsur-unsur seperti interaksi antar pribadi; perbandingan latar belakang budaya. Untuk menjelaskan hal ini Alo Liliweri membagi pengerti "Komunikasi Lintas Budaya" dalam tiga hal. Pertama, "Komunikasi Lintas Budaya" adalah suatu studi tentang perbandingan gagasan atau konsep dalam pelbagai kebudayaan. Kedua, Perbandingan antara satu aspek atau minat tertentu dalam suatu budaya. Ketiga, Perbandingan antara satu aspek atau minat tertentu dalam satu atau lebih kebudayaan. ${ }^{11}$

Lebih lanjut Alo mengutip Fiber Luce untuk memaparkan "Komunikasi Lintas Budaya” yang pada hakikatnya menjelaskan tentang perbandingan (studi komparatif) terhadap variable budaya tertentu, juga konsekuensi atau akibat dari pengaruh kebudayaan, dari dua konteks kebudayaan yang berbeda. ${ }^{12}$ Dengan studi seperti ini diharapkan kelak setiap orang dapat memahami kebudayaan sendiri, sembari di saat bersamaan mengakui bahwa ada pula keutamaan dari kebudayaan orang lain. 2005, hlm 7-8

${ }^{10}$ Mudji Sutrisno \& Hendar Putranto, Teori-teori Kebudayaan, Kanisius, Yogyakarta,

11 Alo Liliweri, Makna Budaya dalam Komunikasi Antar Budaya, LKIS, Yogyakarta, 2002, hlm 18

12 Alo Liliweri, Prasangka dan Konflik, LKIS, Yogyakarta, 2002, hlm 365 
Untuk mewujudkan mimpi itu maka penulis coba menyuguhkan pemaparan tentang realitas kepelbagaian di Bumi Indonesia dari sudut pandang Antropologi Budaya yang memberi dampak baik secara langsung maupun tidak langsung terhadap komunikasi antar dan lintas budaya, khususnya manfaatnya bagi praksis Misi Kristen. 


\section{KOMUNIKASI DALAM KEBUDAYAAN}

Seperti sudah dijelaskan dalam bagian sebelumnya, bahwa komunikasi memiliki tempat dan peranan yang penting dalam budaya. Tidak sekadar sebagai sebuah sarana dalam upaya menjalin relasi sosial, tapi juga sekaligus bagian integral dari budaya itu sendiri. Dalam kebudayaan komunikasi juga kerap dikaitkan dengan seni atau sesuatu yang memiliki unsur estetis. Simpulan ini bukan berarti rumusan tanpa dasar. Komunikasi dalam suatu kebudayaan dikaitkan dengan seni karena memang seni adalah bentuk actual-kreatif dari komunikasi dalam budaya. Dalam kebudayaan, komunikasi, seperti disebut Yakob Tomatala adalah fungsi dari perilaku seni dalam kebudayaan dan seni sendiri adalah perilaku budaya yang memiliki unsur estetika. ${ }^{13}$

Mengapa seni kerap dikaitkan dengan komunikasi, khususnya penggunaannya dalam konteks budaya, karena memang dalam seni terdapat juga unsur komunikasi, dimana proses perpindahan informasi, pesan, symbol atau makna itu terjadi, baik antar individu maupun multi person. Baik bersifat interaktif maupun informative satu arah semata.

Seni bukan sekadar soal interpretasi terhadap sesuatu yang dialihbentukkan dalam ekspresi yang berbeda, tapi seni juga membawa berita, symbol dan makna yang coba disampaikan kepada khalayak (public). Karena itu ekspresi budaya dalam symbol atau lambanglambang tertentu yang bersifat artefak, seperti lukisan, wayang, patung, candi dan lain sebagainya juga adalah bagian dalam perilaku seni yang memenuhi sifat estetik dan komunikatif.

\section{A. Bentuk Komunikasi Dalam Kebudayaan.}

Dalam kebudayaan, komunikasi teraktualisasi dalam wujud yang kian kreatif. Seni sebagai bagian dari aktualisasi itu nyatanya memberi nilai tersendiri terhadap komunikasi. Komunikasi tidak saja terkandung

\footnotetext{
${ }^{13}$ Yakob Tomatala, Antropologi, YTLF, Jakarta, 2007, hlm 221
} 
unsur penyampaian informasi di dalamnya, tapi juga terdapat unsur keindahan, estetika, nilai dan makna. Namun demikian makna yang terkandung pada komunikasi budaya yang teraktualisasi dalam seni bersifat sangatlah subyektif, dalam arti lebih multi interpretative (multi tafsir). Betul, seorang "perancang", atau lebih tepatnya pelaku seni atau seniman memiliki pesan khusus yang disematkan ke dalam karyanya, entah itu karya seni rupa, suara, maupun seni lakon, namun tidak tertutup kemungkinan makna itu ditangkap berbeda oleh penikmatnya. Hal seperti ini memang lazim terjadi dan tidak dapat terhindarkan.

Karena itu, demi efektivitas dan efisiensi dalam proses penyampaian informasi, seorang seniman atau budayawan atau orang yang memanfaatkan seni budaya sebagai sarana menginformasikan pesan haruslah memeras otak sekreatif mungkin. Hal ini dimaksudkan untuk mewujudkan tujuan tersampainya pesan yang diinginkan dengan baik.

Beberapa orang acap membedakan antara seni kaum bangsawan dan seni rakyat. Keduanya memiliki pola, cara, dan pesan (propaganda) berbeda sama sekali. Misalnya di jaman colonial, oleh penjajah rakyat biasa dijejali dengan propaganda, indoktrinasi dan cuci otak bahwa dirinya memang lebih rendah dari penjajah. Penjajah lebih bermartabat, sementara rakyat jelata dipandang tidak ada harganya.

Sementara itu di sisi lain justru suguhan-suguhan seni yang ditampilkan dari rakyat untuk rakyat sama sekali berlainan. Propaganda perjuangan kerap diselipkan dalam setiap lakon, cerita atau drama yang ditampilkan. Pesan bahwa bangsa yang bermartabat adalah bangsa yang merdeka didengungkan, dikisahkan, dituturkan setiap saat dan kesempatan seni itu manggung. Untuk memperoleh pemahaman tentang ekspresi komunikasi dalam budaya diperlukan paparan yang lebih jauh terkait bagaimana pentingnya komunikasi, baik antara budaya maupun lintas budaya.

\section{B. Urgensi Komunikasi Dalam Budaya}


Manusia adalah makhluk social. Itu adalah hakikat dirinya. Sebagai makhluk yang memiliki natur (alami) social, maka keberadaannya tidak dapat dilepaskan dengan lingkungan sekitar, baik benda mati, terlebih makhluk hidup lainnya. Sebagai makhluk social manusia akan berusaha memenuhi hakikat dirinya dengan mengupayakan sosialisasi, menjalin relasi, dan komunikasi dengan dunia atau masyarakat sekitar. Sebagai sarana menjalin hubungan, hanya ada satu alat ampuh yang digunakan, yakni padu-padan simbol yang mengandung makna, yang terjalin, disepakati bersama artinya, dan disebut bahasa. Ya, bahasa, sebuah upaya menanda segala sesuatu dengan rangkaian ucapan yang mengandung arti. Upaya menyepakati sesuatu, kesepakatan memberi arti kepada sesuatu, itu pula yang menjadi bagian dari pembentukan budaya.

Perbedaaan budaya sering dipandang sebagai kekayaan bangsa, meskipun kemajemukan itu tidak jarang juga dipakai orang untuk alasan dirinya melakukan tindakan anarkis terhadap yang berbeda. "Liyan" (the Others), meminjam bahasa Gunawan Mohammad kerap dipandang sebagai batu sandungan, baik dalam sosialisasi diri, maupun penyatuan diri, visi, kesukaan, atau bahkan mimpi. Padahal mengenal kesejatian perbedaan dan kesejatian "liyan" itu akan sekaligus juga menghantarkan orang mengenal diri, memahami diri seutuhnya. Diri yang menyatu dengan bentuk lingkungan, komunitas dan atau konteks budaya yang menjadi latarbelakang unik setiap orang.

\section{Komunikasi Intra Budaya}

Komunikasi intra budaya, atau komunikasi yang terjadi antar anggota dalam suatu kebudayaan yang sama adalah bentuk awal komunikasi yang terjadi dalam masyarakat social, komunitas, etnis dan suku yang skoupnya lebih kecil. Dalam konteks social yang homogen seperti ini, komunikasi tetap berperan penting. Komunikasi di ranah ini terjalin atas kesamaan keinginan, kesamaan tujuan dan pandangan serta nilai-nilai yang sama. Interaksi didalamnya terjalin berkat adanya 
keinginan sesame anggota suatu budaya, kebiasaan-kebiasaan sama yang kemudian mengkristal menjadi pola, nilai-nilai dan world view yang sama. World view yang terbentuk kelak akan berpengaruh terhadap keseluruhan aspek hidup anggota budaya ketika bersinggungan dengan orang yang juga memiliki nilai-nilai berbeda. Tidak itu saja, dalam budaya homogen umumnya komunikasi juga terjalin lebih intensif dibanding dengan komunikasi yang terjadi antar budaya. Komunikasi dalam konteks ini tidak saja menjadi sarana penyampaian pesan dan interaksi semata, seperti dipaparkan pada bab sebelumnya. Bahkan juga menjadi sarana kreatif untuk "tuturtinular" (sharing) ilmu,pengalaman dan nilai-nilai agung antar anggota atau komunitas budaya yang sama.

\section{Komunikasi Antar Budaya}

Komunikasi antar budaya disebut juga komunikasi antar etnik atau ras. Model komunikasi antar budaya melibatkan dua etnik, rasa tau budaya yang berbeda sama sekali. Atau mereka yang berasal dari ras sama, namun memiliki latarbelakang budaya yang berlainan. Komunikasi antar budaya terjalin atau diupayakan untuk terjalin untuk mencari "jalan tengah" atau solusi bagi terpecahkannya symbol atau ide tertentu atau isu tertentu dalam budaya yang berbeda. Selain itu komunikasi antar budaya juga terjalin untuk melakukan pertukaran system symbol dan partisipasi dalam pemberian makna yang sama. ${ }^{14}$

Model komunikasi seperti ini bukanlah sebuah keniscayaan atau harapan yang mungkin diwujudkan. Tapi itu sudah ada dan tentu akan terus ada, mengingat ada beragam saling-silang, carut marut dan abstarksi makna antar budaya yang berbeda sama sekali. Jalinan interaksi antara anggota suatu kebudayaan yang berbeda, keinginan setiap orang untuk berinteraksi, meskipun dengan orang yang ada dalam budaya yang berbeda mengandaikan betapa pentingnya peran komunikasi dalam budaya berbeda. Bagaimana tidak, untuk menyampaikan hasrat,

${ }^{14}$ Alo Liliweri, Prasangka dan Konflik, LKIS, Yogyakarta, 2002, hlm 368 
keinginan, pesan dan maksud tertentu kepada khalayaka berbeda, maka orang harus menyampikan itu dengan cara, symbol dan komunikasi yang dapat dimengerti oleh si penerima. Jika tidak, maka pesan mustahil tersampaikan dengan baik.

\section{Komunikasi Lintas Budaya}

Sebagaimana diketengahkan bahwa komunikasi antar budaya adalah komunikasi antara dua atau lebih etnik, budaya yang berbeda sama sekali, komunikasi lintas budaya sebenarnya juga tidak terlalu berbeda, bahkan cenderung sama jika dilihat dari peserta atau pelaku komunikasi. Perbedaan keduanya, seperti dipaparkan Liliweri terletak pada penekanan aspek "komparatif" atau perbandingan entah itu terhadap sesame anggota budaya atau mereka yang memiliki latar belakang budaya berlainan ${ }^{15}$. Aspek perbandingan ini dimaksudkan bukan hanya bagi konsumsi wawasan komparatif bagi diri atau pribadi, tapi juga bermanfaat focus penyelidikan suatu budaya tertentu demi tujuan-tujuan tertentu yang sudah ditetapkan. Misalnya tujuan menjalin suatu komunikasi yang lebih baik lagi, lebih intens atau demi rekonsiliasi terhadap konflik yang terjadi.

Aspek komparatif mengindikasikan adanya sebuah upaya atau etikat baik untuk menggali informasi, fakta dan relitas budaya yang berbeda, dengan sekaligus berkaca pada budaya sendiri. Disamping itu upaya untuk membandingkan dua budaya yang berbeda dalam konteks komunikasi lebih berkenaan denga bagaimana menyampaikan pesan secara efektif kepada orang yang berlatarbelakang berbeda. Dengan mengerti perbedaan, maka orang akan mencari cara untuk meminimalisir adanya perbedaan itu dalam komunikasi. Sehingga gab yang ada dapat

\footnotetext{
2002, hlm 18

${ }^{15}$ Alo Liliweri, Makna Budaya dalam Komunikasi Antar Budaya, LKIS, Yogyakarta,
} 
semakin dipersempit. Lebih lanjut akan komparasi budaya akan mendatangkan sebuah strategi komunikasi yang efektif, terekspresi tidak hanya pada tataran verbal seperti pemaknaan terhadap kata-kata, kalimat dalam bahasa suara dan tubuh atau dimunculkan symbol-simbol yang unik. 


\section{STRATEGI KOMUNIKASI LINTAS BUDAYA}

Menyampaikan maksud dalam bentuk pesan kepada orang dalam budaya yang berbeda dilakukan orang dari masa ke masa. Mereka yang hidup di masa Perjanjian Lama (PL) dan Perjanjian Baru (PB) pun melakukan hal sama.

\section{A. Komunikasi Lintas Budaya Paulus}

Nama-nama tokoh dalam Alkitab yang sudah familiar seperti Yusuf, Daniel, Nehemia di PL, juga nama-nama para rasul, termasuk Paulus dalam PB, adalah tokoh-tokoh Alkitab yang kerap bersinggungan dengan orang dari bangsa, tradisi, bahasa dan budaya yang notabene berlainan sama sekali. Tuhan Yesus pun juga tercatat pernah melakukan komunikasi lintas budaya.

Dalam kesempatan ini penulis tidak akan memaparkan bagaimana strategi komunikasi mereka satu persatu, tapi mencoba menarik benang merah dari strategi yang digunakan secara umum dan mengambil satu atau lebih contoh dari sekian banyak nama. Paulus menurut penulis dapat dijadikan representasi bagi paparan tentang strategi komunikasi lintas budaya. Pelayanannya yang multi target, tidak hanya kepada orang Yahudi, tapi juga orang bukan Yahudi (Yunani) membuka cakrawala dalam komunikasi lintas budaya.

“Demikianlah bagi orang Yahudi aku menjadi seperti orang Yahudi, supaya aku memenangkan orang-orang Yahudi. Bagi orang-orang yang hidup di bawah hukum Taurat aku menjadi seperti orang yang hidup di bawah hukum Taurat, sekalipun aku sendiri tidak hidup di bawah hukum Taurat, supaya aku dapat memenangkan mereka yang hidup di bawah hukum Taurat.(1 Korintus 9:20)16

\footnotetext{
${ }^{16}$ http://alkitab.sabda.org/bible.php?book=1Kor\&chapter=9\#v20
} 
Ayat ini begitu gamblang menggambarkan bagaimana posisi Paulus ketika dia bersentuhan dengan budaya berbeda. "Menjadi Sama Seperti" tidak berarti harus sama percis (foto copy) dengan target atau budaya yang dituju. Menjadi sama, dalam konteks ini adalah mencoba mendekati budaya yang berbeda dari pemahaman nilai budaya yang mereka miliki. Dengan memahami bagaimana kebiasaan-kebiasaan yang anggota budaya lakukan, yang kelak mengkristal membentuk pola, nilai-nilai world view dan berpengaruh kepada perilaku, adalah sesuatu yang teramat penting. Kalimat "sekalipun aku sendiri tidak hidup di bawah hukum taurat" menjadi penegasan bahwa "menjadi seperti" bukan berarti menjadi sama.

Sebagai seorang Yahudi Paulus tahu benar bagaimana hidup seperti Yahudi, apalagi dia adalah seorang cerdik pandai, pria terpelajar dibawah bimbingan guru besar Gamaliel, tentu tidak dapat dipandang enteng. Sementara kepada orang Yunani, selain Paulus juga memiliki kewarganegaraan Yunani, dia juga mempelajari benar bagaimana cara hidup, filsafat, dan nilai-nilai yang terkandung dalam bangsa Yunani. Dalam pewartaan injil, Paulus kerap memanfaatkan tradisi-tradisi, kebiasaan dan nilai-nilai dalam budaya sebagai jembatan masuknya Injil. Di Atena misalnya Paulus berbicara dihadapan banyak orang Sembari menunggu sahabat-sahabat sepelayanannya, Silas dan Timotius, Paulus memanfaatkan dengan berdiskusi dengan orang-orang yang ada di pasar-pasar.

17:16Sementara Paulus menantikan mereka di Atena, sangat sedih hatinya karena ia melihat, bahwa kota itu penuh dengan patungpatung berhala.17:17Karena itu di rumah ibadat ia bertukar pikiran dengan orang-orang Yahudi dan orang-orang yang takut akan Allah, dan di pasar setiap hari dengan orang-orang yang dijumpainya di situ.17:18 Dan juga beberapa ahli pikir dari golongan Epikuros dan Stoa bersoal jawab dengan dia dan ada yang berkata: "Apakah yang hendak dikatakan si peleter ini?" Tetapi yang lain berkata: "Ruparupanya ia adalah pemberita ajaran dewa-dewa asing." Sebab ia 
memberitakan Injil tentang Yesus dan tentang kebangkitan-Nya. (Kis 17:16-18) ${ }^{17}$

Ketika bersentuhan dengan orang yang berbudaya berbeda Paulus mencermati betul bagaimana kegemaran mereka, nilai yang mereka anut dan world view yang mempengaruhi selurus aspek hidup mereka. Agora menjadi jembatan bagi Paulus untuk menuturkan apa yang dianggap orang di Atena sebagai "ide" atau "wacana" baru. Dalam Kis 17:17 Paulus disebutkan tidak saja berdiskusi dengan orang sesame Yahudi, tapi juga sharing "ide" kepada khalayak di Agora (pasar).

Apa yang dmaksud dengan Agora bukanlah sekadar sebuah pasar. Anton Van Harskamp dalam bukunya menuliskan Agora adalah tempat srategis dimana banyak orang dari multi level dan kalangan berkumpul.

Agora adalah tempat di mana para warga Negara bertemu untuk membahas berbagai masalah yang menyangkut kepentingan umum. Tidak ada keputusan politis yang dibuat di sana: urusan politik dilakukan di tempat lain. Lebih tepat lagi, berjalan santai di alun-alun itu memungkinkan orang untuk terlibat dalam diskusi santai dan perdebatan bebas, untuk menjernihkan masalahmasalah dan memperbaiki wawasan. Karena itu agora merupakan salah satu lembaga public terpentingd ari Negara kota Yunani. Para pedagang, politisi, filsuf, dan warga Negara berbaur, tidak seorangpun memonopoli pasar. ${ }^{18}$

Memanfaatkan agora sebagai lokus pewartaan tidak saja tepat, tapi juga efisien dan efektif. Berbicara soal efisien adalah juga berbicara soal kuantitas, dana dan pembiayaan. Jika coba dikalkulasi dari segi dana atau

\footnotetext{
${ }^{17}$ http://www.sabda.org/sabdaweb/bible/chapter/?b=44\&c=17\&lang=english\&study= onlab/lab/lab/

${ }^{18}$ Anton Van Harskamp, Konflik-konflik dalam Ilmu Sosial,Kanisius, Yogyakarta, 2005, hlm 57
} 
pembiayaan misalnya, maka dengan biaya yang sekecil mungkin, selama beberapa hari, seperti ditulis pada yat ke 17, Paulus dapat menjangkau target yang luar biasa banyak. Bagaimana tidak banyak Paulus memilih tempat di pasar, apalagi pasar yang dimaksud bukan sekadar fungsinya pasar tetapi juga sebuah lembaga informal penting tempat orang berembuik, bertukar pikiran dan menambah wawasan dengan pengetahuan baru.

Selanjutnya pemilihan tempat di pasar juga sangat efisien. Efektif disini berbicara soal bagaimana tepat sasaran atau tepat guna. Selain menjangkau banyak orang, mereka yang menjadi target pemberitaan Paulus pun berasal dari beragam level dan kalangan orang, mulai dari pedagang, politisi, filsuf, dan warga Negara berbaur menjadi satu. Diantaranya disebut juga nama-nama golongan filsuf dan kaum cerdik pandai seperti golongan Epikuros dan Stoa.

Ada beragam respon orang terhadap apa yang Paulus katakan. Mulai dari yang menganggapnya sebagai seorang "peleter" sementara lainnya menilai apa yang dipaparkan Paulus sebagai hal baru yang perlu lebih dalam diketahui. Diskusi pun berlanjut, berpindah dari lembaga informal seperti Agora, menuju lembaga resmi, yakni Areopagus.

17:19Lalu mereka membawanya menghadap sidang Areopagus dan mengatakan: "Bolehkah kami tahu ajaran baru mana yang kauajarkan ini?17:20Sebab engkau memperdengarkan kepada kami perkara-perkara yang aneh. Karena itu kami ingin tahu, apakah artinya semua itu."17:21Adapun orang-orang Atena dan orang-orang asing yang tinggal di situ tidak mempunyai waktu untuk sesuatu selain untuk mengatakan atau mendengar segala sesuatu yang baru. (Kis 17:19-21) ${ }^{19}$

\footnotetext{
${ }^{19} \mathrm{http}: / /$ www.sabda.org/sabdaweb/bible/chapter/?b=44\&c=17\&lang=english\&study= onlab/lab/lab/
} 
Di Areopagus Paulus kemudian menjlentrehkan (memaparkan) tentang apa yang dia yakin dan imani dengan bahasa dan pendekatan local. Bukan sekadar mengetengahkan apa yang menjadi wacana atau opininya, tapi Paulus juga melakukan serangkaian observasi terlebih dahulu. Melihat situasi dan kondisi sekitar, apa yang mencolok, dan merumuskan sedemikian rupa apa yang diobservasi itu untuk dijadikan jembatan masuk bagi pesan, atau informasi yang hendak Paulus sampaikan. Meski demikian respon tidak selalu positif diterima Paulus. Benar jika dikatakan respons adalah hal penting untuk mengukur sejauh apa efektifitas metode atau strategi yang diterapkan. Tapi terlalu berkutat pada respons juga kurang baik, mengingat respons sifatnya sangat subyektif dan cenderung relitifis. Selanjutnya metode Paulus dan prinsip-prinsip yang diterapkannya akan diulas lebih lanjut pada bagian selanjutnya.

\section{B. Strategi Komunikasi Lintas Budaya}

Strategi berkaitan erat dengan eksekusi, pelaksanaan atau aktualisasi. Namun demikian, yang menjadi pertanyaannya adalah, aktualisasi dalam hal apa, atau apa yang hendak di eksekusi. Wikipedia menyebutkan, dalam strategi, yang dieksekusi adalah keseluruhan pendekatan yang bersinggungan erat dengan pelaksanaan sebuah gagasan, atau perencanaan. Dari uraian ini nyata terlihat bahwa dalam strategi tidak hanya ada unsur ide, gagasan, atau rencana tertentu, lebih dari itu, juga melibatkan aspek praksis. Bagaimana mengejawantahkan rencana menjadi sesuatu yang nyata adalah hal yang tidak mungkin dikesampingkan.

Lebih lanjut, strategi yang dikorelasikan dalam konteks komunikasi, seperti yang KBBI paparkan, hal itu adalah sesuatu yang patut dikerjakan demi kelancaran komunikasi. Tentu saja melibatkan banyak aspek. Dalam budaya misalnya, untuk mewujudkan kelancaran 
dalam komunikasi sesama anggota budaya saja, seperti diulas dalam babbab sebelumnya begitu rumit. Apalagi jika strategi tersebut menyentuh budaya yang berlainan, silang budaya (cross-cultural),multi kultur, atau pluri-kultur, pastilah tingkat kesulitannya lebih tinggi.

Bertolak dari model komunikasi lintas budaya yang telah diterapkan oleh Paulus, penulis hendak menelisik lebih jauh terkait strategi komunikasi lintas budaya yang diterapkan, dengan berusaha sedapat mungkin mendekati aspek-aspek penting dalam komunikasi lintas budaya.

\section{Pemaknaan The Others}

Pemaknaan yang tepat terhadap liyan (the others) adalah sesuatu yang tidak mungkin dihindari. Dengan menempatkan liyan pada posisi yang tepat, berindikasi besar menghindarkan konflik yang ditimbulkan oleh diskriminiasi, perlakuan subordinasi terhadap liyan, pelecehan atau penempatan liyan sebagai tak lebih dari "objek" semata. Liyan atau the others umumnya tidak sekadar dimaknai sebagai oknum atau pribadi atau sesuatu yang berbeda, lebih dari itu, dalam the others terdapat pemaknaan yang sangat negative penuh nuansa diskriminatif.

"Siapakah the others itu? Mereka adalah orang asing. Dan yang asing itu berarti adalah makhluk yang berada di luar hubungan darah (etnos) dalam sebuah bangsa, dank arena itu sah untuk dibinatangkan (barbar). Dalam tradisi Romawi Kuno, "the others" adalah "homo barbarous" (manusia asing, tetapi juga bias diartikan [maaf] "anjing").20

Upaya pelabelan terhadap orang yang berbeda dengan cara seperti ini, penuh dengan kebencian, merendahkan orang sekaligus mengagap diri lebih superior

\footnotetext{
2004, hlm 38

${ }^{20}$ Mudji Sutrisno, Hermeneutika pascakolonial: soal identitas, Kanisius, Yogyakarta,
} 
sementara yang lain inferior, tidak hanya dapat ditemui di masa lampau saja. Di era sekarang ini eksklusivitas diri, kelompok, organisasi dan agama juga kerap dijadikan alasan untuk menganggap diri lebih utama daripada yang lain, menggap diri lebih kudus dari yang lain, atau anggapan diri lebih "dikehendaki" oleh Tuhan. Rasanya tidak asing lagi istilah "kafir", "sesat", "bidat" bagi orang atau oknum berbeda iman, ide atau wacana yang dipegang. Atau kepada orang yang mungkin saja mendapat "iluminasi" berbeda dari interpretasi terhadap teks.

Di Indonesia, pada masa colonial istilah pribumi non pribumi juga menjadi suatu hal yang kental warna pelecehan. Bangsa kulit putih (colonial) dianggap lebih intelek, diangap kaum cerdik pandai dibanding bangsa pribumi. Atau golongan pedagang dari etnis tionghoa yang menganggap diri memiliki level lebih tinggi bila dibandingkan dengan orang bumi putra yang kala itu notabene adalah buruh rendah (baca: kuli).

Menempatkan orang tidak pada tempatnya. Menjadikan orang sekadar sebuah objek. Membendakan orang adalah tindakan-tindakan yang sangat tidak terpuji dan bertentangan dengan Alkitab. Kristen, sebagaimana tertulis dalam Alkitab, memandang manusia dalam substansi segambar dan serupa dengan Allah.

"Berfirmanlah Allah: "Baiklah Kita menjadikan manusia menurut gambar dan rupa Kita, supaya mereka berkuasa atas ikan-ikan di laut dan burung-burung di udara dan atas ternak dan atas seluruh bumi dan atas segala binatang melata yang merayap di bumi."(Kejadian 1:26)

Sebagai ciptaan yang memiliki substansi segambar dan serupa dengan Allah, manusia menerima "akibat", dampak atau konsekuensi tertentu dalam artian positif. Akibat-akibat itu mengemuka dalam bentuk naturnatur tertentu yang dikomunikasikan Allah kepada ciptaan-Nya, manusia. Dengan natur-natur itu manusia dapat melakukan sesuatu, berkarya dan 
menganalisa, bahkan mencipta, meskipun yang dicipta an-sich merupakan peralihan substansi semata. Konsekuensi segambar dan serupa dengan Allah juga mewujud dalam diri manusia sebagai pribadi. Allah yang berpribadi menjadi dasar untuk menunjuk pada manusia yang berpribadi pula.

Karena itulah penting sekali menghargai manusia sebagai mana khitahnya (kesejatian/ seharusnya) sebagai manusia. Merujuk keunikan yang di miliki oleh manusia sebagai konsekuensi dari kesegambaran dengan Allah, salah satunya maujud (mewujud) dalam karsa kreatif manusia, maka orang juga harus menghargai karya-karya kreatif manusia. Budaya adalah salah satu hasil dari karya dan karsa, budi dan daya manusia dengan natur kreatifnya.

"salah satu unsur kesegambaran adalah kreativitas yang ada pada manusia yang mengungkapkan "lingkup kebebasan" yang dikaruniakan Allah kepada manusia itu. Kreativitas manusia inilah yang menjadi landasan ia mengembangkan kebudayaannya dalam upaya mempertahankan dan melanjutkan kehidupannya."21

Sebagai seorang Rasul pewarta Injil Kristus, orang yang dipilih, tidak sekalipun Paulus mengagap diri lebih superior dari orang yang belum dipanggil Allah. Kerinduannya untuk selalu mewartakan Injil di manapun dia berada adalah bentuk kecintaanya itu. Baginya jiwa adalahy sesuatu yang lebih berharga dari dirinya sendiri. Mewartakan Kristus sesuatu yang lebih utama daripada sekadar jabatan. "Sementara Paulus menantikan mereka di Atena, sangat sedih hatinya karena ia melihat, bahwa kota itu penuh dengan patung-patung berhala. (17:16). Realitas "berhala" sebagai penanda orang-orang di tempat itu belum mengenal Kristus; atau jiwa-jiwa yang tersesat membuat Paulus menjadi sedih.

${ }^{21}$ Yakob Tomatala, Antropologi, YTLF, Jakarta, 2007, hlm 122 
Karena itu "sharing iman" Paulus adalah sekaligus bentuk kecintaannya pada orang-orang yang diajak berbagi. Bentuk penempatan cara pandang yang tepat terhadap jiwa-jiwa manusia yang sejatinya sama, segambar dan serupa dengan Allah itu belum mengenal kesejatiannya.

\section{Memahami Nilai-nilai Budaya Liyan}

Tidak cukup dengan pandangan atau cara pandang yang tepat terhadap liyan, diperlukan juga pemahaman yang lebih mendasar dan mendalam terhadap unsur-unsur dalam budaya. Salah satu yang utama menurut penulis adalah unsur nilai-nilai dalam budaya. Mengapa utama, karena unsur-unsur nilailah yang kelak membentuk world view orang selaku anggota dalam suatu kebudayaan. Unsur-unsur yang sama juga disentuh oleh Paulus dalam pelayanannya di Athena. Meski ada indikasi Paulus telah familiar benar dengan diskursus ide di masa itu, atau bagaimana kondisi budaya di Athena, mengingat Paulus adalah murid dari guru besar Gamaliel, namun tidak berarti Paulus lantas abai untuk kembali menggali informasi lebih mendalam tentang unsur ini. Ada beberapa hal yang dilakukan Paulus yang menjadi sinyalemen upaya pencarian informasinya:

\section{a. Observasi}

Observasi adalah langkah awal yang dilakukan Paulus ketika tiba di Atena. Pengamatan terhadap lingkungan sekitar, situasi dan kondisi, juga apa yang menghiasi dan mewarnai sejauh mata Paulus memandang. Apa yang diamati? Hal yang membuat Paulus tertarik sekaligus simpati adalah banyaknya patung-patung berhala di kota itu. Patung-patung itulah yang kemudian menjadi sarana penting dalam menjalin komunikasi. Patung berhala dimanfaatkan Paulus sebagai jembatan dalam memantik berlangsungnya komunikasi. Di sini patung-patung berfungsi ganda. Selain sebagai pemantik komunikasi, patung-patung dimaksud adalah 
sekaligus bagian penting dari nilai-nilai kultural dan religious kebudayaan. Nilai religio-kultural ini selanjutnya coba dieksplorasi Paulus lebih lanjut dalam penggalian informasi melalui saling bertukar pikiran, baik dengan orang-orang yang kebudayan dan nilainya sudah dikenal Paulus, maupun orang dari kebudayaan dan tingkatan berbeda, yang ansich Paulus telah kenal dalam studinya. Informasi Tentang hal ini dapat dilihat pada Kisah Para Rasul 17:16.

\section{b. Interview}

Setelah mengamati apa yang ada di sekitarnya, Paulus menggali informasi lebih dalam dengan cara berdialog, menjalin komunikasi dengan orang-orang yang ditemuinya. Ada dua lokus dan subyek/ lawan komunikasi berbeda yang menarik untuk ditilik hal apa di balik itu. Pertama adalah di rumah ibadah dan bertemu orang-orang Yahudi. Berbincang tentang sesuatu dengan orang yang memiliki nilai, budaya dan world view serupa tentu akan jauh lebih mudah. Informasi yang diharapkan pun jauh lebih cepat didapat. Ada indikiasi topic yang dibincangkan pun terkait dengan observasi yang telah dilakukan oleh Paulus, yakni soal patung-patung berhala yang memenuhi kota Atena. Namun demikian masih menyisakan gap dan Tanya. Pasalnya informasi yang didapat Paulus tidak berasal dari sumber pertama, orang dengan budaya dan nilai itu sendiri.

Kedua, Paulus berbicara di Agora (pasar). Di tempat ini Alkitab mencatat proses penggalian informasi dilakukan Paulus terhadap setiap orang yang dijumpainya di situ. Alkitab pun mencatat proses ini dilakukan Paulus setiap hari, bukan hanya satu hari. Di Agora seperti dipaparkan sebelumnya ada begitu banyak orang dari berbagai kalangan dan latar belakang profesi. Pedagang, politisi, rakyat jelata, semua berbaur menjadi satu saling bercengkrama membincangkan banyak hal. Lokasi yang dipilih Paulus ini adalah tempat yang tepat. Bukan saja 
informasi tentang patung-patung berhala didapat dari sumber pertama, orang yang hidup dan menghidupi nilai dibalik patung, tapi juga mendapat pandangan dengan pendekatan yang beragam. Bahkan orang-orang dengan kecerdasan intelektual tinggi juga sempat bersoal jawab dengan Paulus. "Beberapa ahli pikir dari golongan Epikuros dan Stoa bersoal jawab dengan dia". Meskipun kesan pertama mereka terhadap Paulus terekspresi negative, "Apakah yang hendak dikatakan si peleter ini?". Tapi bukan berarti Paulus tidak mendapat simpati dari upayanya menjaring informasi dan bersoal jawab. Pendekatan dan proses penggalian informasi juga membuka wawasan piker orang, bahkan menghantarkannya pada sharing wacana di tempat yang terhormat, yakni Areopagus.

\section{Jembatan Silang Budaya.}

Interaksi lebih mendalam dilakukan Paulus ketika dia diminta untuk memaparkan ide-ide dan wacana pada wahana/ forum/ lembaga yang lebih resmi, yakni Areopagus. Di sini uraiannya dimulai dengan hasil pengamatannya selama ini dengan menunjuk pada aspek positif, yakni kesetiaan orang-orang Athena kepada dewa-dewanya, meski hal itu mereka tujukan pada "oknum" yang tidak dikenal..

"Paulus pergi berdiri di atas Areopagus dan berkata: "Hai orangorang Atena, aku lihat, bahwa dalam segala hal kamu sangat beribadah kepada dewa-dewa. Sebab ketika aku berjalan-jalan di kotamu dan melihat-lihat barang-barang pujaanmu, aku menjumpai juga sebuah mezbah dengan tulisan: Kepada Allah yang tidak dikenal. Apa yang kamu sembah tanpa mengenalnya, itulah yang kuberitakan kepada kamu." (Kis 17:22-23)

Menarik, bukan pendekatan konfrontasi langsung yang mengawali ulasannya. Bukan juga langsung mengarah kepada focus utama yang 
hendak dibicarakannya. Tapi mencoba mendekati audiens, pendengarnya dengan cara meninggikan hati, menunjukkan kebaikan, hal-hal positif dengan menggunakan kalimat pujian. Kalimat ini juga yang menjadi jembatan bagi Paulus untuk melangkah pada materi yang lebih mendalam.

Hal mengesankan yang dibuat oleh Paulus selanjutnya adalah dengan menunjukkan kepada audiensnya tentang ada sesuatu berbeda yang dia lihat berdasarkan observasi dan interview yang dilakukannya. Sesuatu dimaksud masih memiliki kaitan dengan pujian dia sebelumnya, yakni barang-barang pemujaan, mezbah dengan tulisan: Kepada Allah yang tidak dikenal. Di sini dapat dilihat strategi penginjilan Paulus yang benar-benar peka terhadap konteks dan memanfaatkan pengetahuan iman mereka yang juga wahyu umum Allah itu. Paulus juga tidak mengecam berhala-berhala sesembahan mereka. Sebaliknya, ia justru memakai salah satu berhala yang tidak bernama untuk memperkenalkan Allah yang disembahnya. Celah ini kemudian dimanfaatkan benar oleh Paulus untuk membuka wawasan berpikir pendengarnya. Bagaimana mungkin seseorang menyembah Tuhan tanpa dia mengenal Dia? Namun ketidakmengertian itulah yang hendak dijelaskan Paulus.

Pokok perbicangan Paulus selanjutnya adalah kupasan dia tentang siapakah Allah yang sejati itu, bertolak dari pengetahuan dan kepercayaan pendengarnya. Paulus memperkenalkan Allah sebagai Sang Pencipta langit dan bumi serta segala isinya. Dia adalah pribadi yang berdaulat penuh atas segala ciptaan-Nya, termasuk manusia. Hidup manusia berasal dari juga bergantung penuh kepada Allah, dan bukan sebaliknya. Karena itu Allah yang sejati bukanlah dilayani oleh tangan manusia, seolah-olah Ia kekurangan apa-apa. Sebaliknya, justru manusialah yang dependen terhadap-Nya. Karena Dialah yang memberikan hidup, nafas dan segala sesuatu kepada semua orang 
Selanjutnya, yang dilakukan Paulus adalah memanfaatkan konsep nilai yang dipegang teguh oleh orang-orang Athena bahwa mereka adalah keturunan allah (dewa). "Seperti yang telah juga dikatakan oleh pujanggapujanggamu: Sebab kita ini dari keturunan Allah juga." Betul-betul mengesankan, disini Paulus menyuguhkan kepada aduiensnya tentang logika berpikir atau konsekuensi berpikir. Jika orang mengaku sebagai keturunan Allah, maka implikasinya adalah konsep, paradigma berpikir tentang Allah harus dirubah. Orientasi berpikir tentang Allah dikaitkan dengan hal-hal materi harus dirubah. Sebab keadaan, situasi atau kondisi ilahi/ keilahiaan sama sekali berbeda dengan substansi materi, meskipunj itu logam mulia sekalipun, seperti emas,perak, batu, atau barang berharga lainnya ciptaan kesenian dan keahlian manusia. Allah adalah pencipta materi. Allah supra materi, atau melintasi materi. Karena itu Allah tidak mungkin dikungkung, dikurum kedalam materi.

Hal yang selebihnya diunjukkan Paulus adalah ulasannya tentang sebuah reinterpretasi terhadap budaya. Budaya dengan segala nilai-nilai yang diam di dalamnya diubah sedemikian rupa. Paulus kemudian memperkenalkan cara beribadah yang benar di hadapan Allah. Bagaimana bersikap yang benar di hadapan Dia yang Mahabesar. Tetapi memposisikan diri kepada Allah, Tuihan yang disembah itu tepat pada proporsinya. Ibadah yang benar bukan dengan menyembah berhala, melainkan dengan menjalani kehidupan yang kudus, yang berkenan kepada-Nya. terlebih lagi, kehidupan yang dijalani pun harus dipertanggungjawabkan kelak di hadapan Dia. Karena itu tidak saja sikap gentar terhadap-Nya yang dibutuhkan, tapi juga merendahkan diri, pengakuan dosa dalam pertobatan adalah langkah awal untuk menghormati Dia, dan setia kepada-Nya 


\section{A. Kesimpulan}

Berkomunikasi adalah aktifitas sehari-hari orang yang tidak mungkin dihilangkan. Komunikasi bukan saja hal yang biasa dilakukan, tapi sudah menjadi bagian kebutuhan orang yang tidak mungkin terpisahkan. Apalagi manusia adalah makhluk social yang memerlukan jalinan interaksi. Dalam berinteraksi, tidak akan mungkin dua atau lebih orang terhubung dalam sebuah jalinan tanpa adanya komunikasi.

Dalam konteks budaya yang banyak memiliki kesamaan, serasa tidak ada penghalang orang dalam berkomunikasi. Ada banyak materi atau bahan bagi orang yang dapat dibagikan dan perbincangkan. Tapi tidak dengan berkomunikasi kepada orang-orang dengan kebudayaan berbeda. Tidak saja dari aspek kebiasaan orang saja yang berbeda. Norma-norma berbeda, lebih dari itu ada kepelbagaian, ada kemajemukan yang berpotensi menghasilkan gap dalam berkomunikasi. Nilai-nilai yang dipegang orang, paradigm berpikir, world view yang berbeda menjadi penghalang utama orang dalam berkomunikas, mengingat hal-hal yang disebut merupakan sesuatu yang sudah mengkristal sejak lama. Sesuatu yang dibentuk oleh tempaat lingkungan, ajaran, maupun nilai-nilai yang disepakati bersama. Dan bila aspek ini secara frontal dikonfrontasikan dengan nilai berbeda, maka dampaknya tidak saja penolak, kemungkinan besar juga anarkis.

Hal-hal berkaitan dengan nilai seperti ini tidak boleh dianggap enteng, harus disiasati sedemikian rupa, sehingga memberikan jalan bagi orang untuk berinteraksi dalam jalinan komunikasi. Sama seperti yang dilakukan oleh Paulus kepada penduduk Athena. Dia tidak serta merta berdebat konfrontatif dengan mereka, tapi menjalin strategi yang matang dengan proses yang tidak pendeka, setidaknya Alkitab mencatat berharihari lamanya. Kendati hasilnya tidak seperti diharapkan, namun upaya mengkomunikasikan, menginformasikan pesan kepada subyek berbeda yang dilakukan Paulus patut diacungi jempol. Bahkan apa yang Paulus lakukan patut dijadikan sebagai teladan. 


\section{B. Rekomendasi}

Era lampau maupun kekinian komunikasi tetap dibutuhkan, apalagi oleh mereka yang menyatakan diri sebagai hamba Tuhan. Proses pengumpulan informasi dengan cara observasi dan interview adalah contoh yang baik dilakukan sebelum hamba Tuhan melayani di daerah tertentu. Hal seperti ini menolong hamba Tuhan untuk mengenal dengan baio "obyek" atau target Injil di mana mereka akan mewartakan. Dengan mengenal, berarti mereka juga akan mengerti kebutuhan-kebutuhan mendasar, pertanyaan mendasar, atau7 celah tertentu yang olehnya Injil memperoleh jembatan untuk masuk.

\section{KEPUSTAKAAN}

1. Yakob Tomatala,

2007 Antropologi, Jakarta: YTLF

2. Tommy Suprapto,

2008 Pengantar Teori dan Manajemen Komunikasi, Yogyakarta: MedPress,

3. Alo Liliweri,

2002 Makna Budaya dalam Komunikasi Antar Budaya, Yogyakarta: LKIS

2002 Prasangka dan Konflik, Yogyakarta: LKIS

4. Mudji Sutrisno,

2005 Teori-teori Kebudayaan, Yogyakarta: Kanisius

2004 Hermeneutika pascakolonial: soal identitas, Yogyakarta: Kanisius

5. Anton Van Harskamp,

2005 Konflik-konflik dalam Ilmu Sosial, Yogyakarta: Kanisius

6. Kamus Besar Bahasa Indonesia http://kbbi.web.id/index.php?w=komunikasi

7. http://id.wikipedia.org

8. www.sabda.org 